\title{
MENGUJI MODEL HUBUNGAN ANTARA ORGANIZATION-BASED SELF ESTEEM TERHADAP ORGANIZATONAL CITIZENSHIP BEHAVIOR; SELF EFFICACY SEBAGAI VARIABEL PEMEDIASIAN
}

\author{
Susi Widjajani \\ Joko Wiyono \\ Mia Rahma Romadoni \\ Universitas Proklamasi 45 Yogyakarta \\ e-mail : susi_wijayani@yahoo.co.id
}

\begin{abstract}
Organizational behavior is a reflection of the attitudes and behaviors of employees who believed based on the perception of the individual to improve their performance. The purpose of study will describe the influence of organization-based self-esteem (OBSE) on organizational citizenship behavior (OCB) mediated self efficacy. The research was quantitative methode and to collect data using instruments measuring instrument adapted from self-efficacy (Bandura, 1997), OBSE (Pierce, Gardner, Cummings, \& Dunham, 1989, 1993) and OCB (Williams \& Anderson, 1991). Samples of the research were hospital employees, group D both medical and nonmedical employees in the region of Yogyakarta Province. Results of the factor analysis with SEM using AMOS version 18, describes relationship OBSE on OCB both directly and mediated by self-efficacy in the work environment within the scope of the valueattitude-behavior.
\end{abstract}

Keywords: Organization-based Self-esteem, Self-Efficacy, Organizational Citizenship Behavior

\begin{tabular}{l}
\hline PENDAHULUAN \\
${ } }$ \\
anggota organisasi sangat berperan menentukan \\
keberhasilan organisasi dalam mencapai tujuan- \\
nya. Robins dan Judge (2009) menjelaskan \\
bahwa perilaku organisasi merupakan perilaku \\
yang dimiliki individu, kelompok, dan organisasi \\
yang terstruktur, bertujuan untuk meningkatkan \\
efektifitas suatu organisasi. Peran serta karyawan \\
merupakan cerminan rasa memiliki mereka \\
terhadap organisasinya yang akan berdampak \\
positif terhadap perilaku yang diharapkan \\
dapat membantu kinerja organisasi (Van Dyne \\
\& Pierce, 2004). Perilaku ideal karyawan
\end{tabular}

merupakan perilaku yang secara tidak secara formal ada namun sesuai dengan harapan organisasi, merupakan perilaku yang diharapkan oleh organisasi untuk dapat mempertahankan efektifitas dan efisiensi organisasinya yang disebut sebagai Organizational Citizenship Behavior (OCB) (Suresh \& Venkatamal, 2010). OCB memiliki dua model, yaitu OCB-Individu yang secara langsung mempengaruhi perilaku individu dan OCB-Organization yang secara langsung mempengaruhi organisasi (Suresh \& Venkatamal, 2010).

Perilaku individu dipengaruhi oleh persepsi kognitif yang akan membentuk sikap terhadap sesuatu yang dihadapi. Pierce dan 
Gardner (1998) menyatakan pentingnya peranan konsep diri karyawan dengan paradigma organisasi terhadap aktivitas mereka ditempat kerja. Efikasi diri karyawan dapat mempengaruhi tingkat keinovatifan organisasi dan membantu pencapaian tujuan organisasi (Kumar \& Uzkurt, 2013). Ada tidaknya harga diri dalam organisasi atau OBSE menjelaskan kedekatan hubungan karyawan dengan organisasinya (Pierce dkk, 1993). Pada penelitian terdahulu yang pernah dilakukan oleh Cotril (2011) yang menemukan bahwa organisasi mendukung lingkungan khusus bagi manager madya pada kepemimpinan otentik dan iklim organisasi yang etis, dan mendukung lingkungan khusus bagi karyawan untuk memiliki harga diri dan kesadaran untuk mau mengerjakan pekerjaannya ataupun yang lainnya. Hal tersebut selaras dengan pendapat Van Dyne dan Pierce (2004) yang berargumen bahwa sikap yang positif karyawan seperti OBSE, komitmen serta sikap positif lainnya dapat mempengaruhi OCB. Selanjutnya ada penelitian dari Conley (2006) yang meneliti mengenai OBSE dan Efikasi diri didasarkan atas pernyataan dari (Gardner \& Pierce, 1998) tentang harga diri dan efikasi diri memiliki dampak positif terhadap kinerja dan sikap kerja yang relevan pada karyawan. Hasil penelitan Conley (2006) menemukan bahwa efikasi diri dan variabel demografi seperti usia, lama bekerja dan jabatan adalah saling berhubungan, namun sebaliknya hubungan OBSE dengan variabel demografi secara statistik tidak signifikan berhubungan. Sedangkan OBSE dan efikasi diri memiliki hubungan yang signifikan.

Variabel-variabel peneltian ini telah banyak di teliti oleh para peneliti sebelumnya, namun secara fundamental belum ada yang mengkaji dari ketiga variabel OBSE, efikasi diri dan OCB-I dan OCB-O. Kebaruan penelitian ini adalah melibatkan variabel OBSE, efikasi diri dan OCB-I serta OCB-O yang menjelaskan tahapan pembentukan perilaku dari value-beliefdan attitude. Penelitian ini bertujuan untuk menjelaskan dinamika pengaruh OBSE dan efikasi diri terhadap OCB (OCB-I dan OCB-O) yang mencerminkan nilai-sikap-perilaku individu dalam dunia kerja sebagaimana konsep dasarnya yaitu mengenai sikap-persepsi-perilaku anggota organisasi secara kolektif dapat mendukung kinerja/perilaku organisasi. Berdasarkan penjelasan di atas maka pembahasan mengenai OBSE, efikasi diri, dan OCB dirasa penting untuk dibahas, karena dapat mengetahui peran konsep diri karyawan terhadap kinerja organisasi dengan pertanyaan: "Apakah ada pengaruh positif antara OBSE terhadap OCB (OCB-I dan OCB-O) yang dimediasi oleh Efikasi Diri Karyawan?”.

\section{REVIEW LITERATUR DAN HIPOTESIS}

\section{Harga Diri dalam Organisasi/Organization- based Self Esteem (OBSE)}

Harga diri dalam lingkup organisasi (Pierce, Gardener, Cummings, \& Dunham, 1993, 1989) yaitu:

The degree to which organizational members believe that they can satisfy their needs by participating in roles within the context of the organization. ... organization-based self-esteem reflects the self-perceived value that individuals have of themselves as organizational members acting within an organizational context (Pierce, Gardner, Cummings, \& Dunham, 1989.)

Dasar teori OBSE berasal dari konsep diri dari Korman (1976) bahwa individu memiliki pengalaman yang berharga mengenai kemampuannya, sehingga membentuk kepuasan mereka akan terlibat pada suatu penyelesaian/ peristiwa yang berharga dan membentuk harga diri. Ketika karyawan dengan OBSE tinggi seharusnya dirasakan oleh mereka sendiri sebagai sesuatu yang penting, bermakna, efektif, dan bermanfaat bagi organisasinya. 
Enam pilar pembentuk harga diri dari Branden's (Kreitner \& Kinicki, 2004) yaitu: pertama, live conseciously adalah anggota organisasi menjadi aktif dan pengikat yang kuat ketika berinteraksi dengan anggota organisasi yang lain. Kedua, be self-accepting yaitu individu/ anggota organisasi tidak boleh berlebihan menilai ataupun mengkritik pikiran dan aksinya sendiri. Ketiga, take personal responsibility yaitu menjadi anggota organisasi yang memiliki tanggung jawab dalam memutuskan dan beraksi dalam perjalanan hidupnya ataupun kelompoknya. Keempat, be self-assertive merupakan keaslian dan kerelaan anggota organisasi untuk berani menyatakan pendapat secara jujur tanda ada kecenderungan untuk mendapatkan perhatian/ berani menyatakan pendapatnya. Kelima, live purposefully adalah anggota organisasi memiliki tujuan jangka pendek dan panjang dengan rencana yang realistis untuk mencapainya dengan mengontrol keseluruhan kehidupannya. Dan keenam have personal integrity karena menjadikan kebenaran sebagai nilai diri anggota organisasi. OBSE menggambarkan penilaian diri anggota organisasi yang merasa berkompeten untuk berkontribusi terhadap organisasinya (Pierce dkk, 1989).

Harga diri pada diri anggota organisasi yang tinggi dapat berfungsi secara aktual untuk mendukung kemampuan mereka pada tugas yang khusus sehingga membantu mereka dalam menyelesaikan tugas-tugas yang lebih berat (Mossholder, dkk, 1982). Hal itu didasarkan pada konsep bahwa secara konsep harga diri merupakan aspek psikologis yang mempengaruhi kemampuan karyawan sehingga mereka mampu terampil dan menyelesaikan pekerjaannya untuk mencapai kinerja yang baik (Conley, 2006; Mossholder, dkk, 1982; Pierce, dkk, 1993). Ditandaskan pula oleh Pierce dkk (1993) bahwa OBSE berhubungan dengan persepsi seseorang mengenai personal value pada konteks organisasi, sikap dan persepsi mengenai OBSE secara teoritik dan empirik mempengaruhi perilaku individu. Pierce dkk (1989) yang menjelaskan bahwa karyawan yang memiliki OBSE yang tinggi maka mereka akan merasa penting, berarti, dekat, dan dihargai ketika bekerja di dalam organisasinya. Pentingnya OBSE adalah dapat memberikan kontribusi positif terhadap kinerja organsiasi sehingga karyawan memiliki komitmen yang tinggi untuk mencapai target atau tujuan bersama (Pierce, dkk, 1989).

\section{Efikasi Diri}

Efikasi diri didefinisikan oleh Bandura (1997) sebagai derajat keyakinan seseorang akan kemampuannya dalam menyelesaikan tugas pekerjaannya dan mencapai hasil tertentu. Choi, Price, dan Vinokur (2003) menjelaskan efikasi diri sebagai keyakinan yang secara signifikan memprediksi perilaku untuk memilih pencapaian tujuan, upaya penyelesaian tugas dan kinerja yang aktual. Bandura dengan teori efikasi diri baik individu ataupun kolektif memiliki fokus pada keyakinan akan kemampuan dan diaktualkan dengan perilaku/kinerja yang bertujuan untuk mencapai tujuan (Conley, 2006). Efikasi diri secara nyata dan langsung mempengaruhi kinerja, karena dapat memperoleh keyakinan akan kemampuan diri untuk menyelesaikan tugas khusus menjadi lebih nyata (Conley, 2006; Schepman \& Richmond, 2003). Dijelaskan pula oleh Copper (2010) bahwa konstruk dari efikasi kolektif adalah teori sosial kognitif dan hubungan antar manusia dari hubungan sebab akaibat yang timbal balik secara triadic.

Efikasi diri terdiri dari tiga dimensi (Bandura, 1997), yaitu: pertama, Magnitude merupakan keyakinan dalam menyelesaikan tugas berdasarkan tingkat kesulitan pekerjaan yang dihadapi. Kedua, Strength merupakan tingkat kekuatan keyakinan untuk dapat menyelesaikan tugas pekerjaannya. Dan ketiga, Generality merupakan keyakinan dalam menyelesaiakn berbagai tugas yang berbeda dan membutuhkan 
cara khusus untuk menyelesaikannya. Dikatakan pula oleh Bandura (1997) bahwa efikasi diri mencerminkan satu keyakinan mengenai perilaku khusus yang berasal dari konsep kognitif dan perilaku mengenai kemampuan dan ketrampilan dalam menghadapi situasi atau kondisi tertentu. Hal itu dikarenakan pembentukan efikasi diri dipengaruhi oleh persepsi dan mencontoh perilaku yang diadopsi dari lingkungan dan kondisi dimana indvidu berada (Conley, 2006; Strauser, dkk, 2002) berdasarkan dari teori social cognitive beahvior dari Bandura. Berdasarkan pendapat tersebut maka ketika efikasi karyawan rendah maka perilaku yang muncul tidak akan sesuai dengan yang diharapkan begitu sebaliknya (Conley, 2006). Keyakinan efikasi diri pada diri seseorang adalah sebagai prediktor yang baik untuk perilaku individu (Tschannen-Moran, \& Garesin, 2004).

\section{Perilaku Ideal dalam Organisasi/ Organizational Citizenship Behavior (OCB)}

Organ (1988) menjelaskan bahwa OCB merupakan perilaku yang merupakan pilihan dan inisiatif individu, tidak terkait dengan sistem reward yang berlaku pada organisasi, tetapi merupakan keinginan untuk meningkatkan efektivitas organisasi. Organizational citizenship behavior menurut Chein (2004) adalah:

"individual behavior that is discretionary, not directly or explicitly recognized by the formal reward system and that in the aggregate promotes the effective functioning of the organization"

Dapat disimpulkan bahwa OCB merupakan perilaku individu yang bersifat ideal karena merupakan gambaran perilaku yang positif di luar harapan dan tanggung jawabnya. Terdapat lima dimensi pembentuk OCB (Organ, 1988; William \& Anderson, 1991), yaitu: 1) Altruisme yaitu perilaku memberikan pertolongan pada hal yang bukan menjadi tanggung jawabnya. 2) Courtessy merupakan perilaku menghargai dan memperhatikan orang lain. 3) Sportsmanship merupakan perilaku toleransi pada organisasinya tanpa mengajukan keberatan. 4) Conscientiousness merupakan perilaku sukarela karyawan pada organisasinya. Dan 5) Civic Virtue merupakan perilaku bertanggung jawab pada kehidupan organisasi untuk meningkatkan kinerjanya.

OCB terdapat dua fokus (William \& Anderson, 1991), yaitu: pertama OCB-Individu dengan target perilaku tertuju pada individu tersebut yang berdampak pada organisasi dan bermanfaat untuk meningkatkan efektifitas dan efisiensi organisasi, terdiri dari dua dimensi yaitu altruisme dan courstesy. Kedua, OCBOrganisasi dengan target perilaku yang tertuju secara langsung terhadap organisasi, sehingga bermanfaat bagi peningkatan efektifitas dan efisiensi organisasi, terdiri dari tiga dimensi, yaitu: civic virtue, consientousness, dan sportmanship. Chih, Yang, dan Chang (2012) menjelaskan bahwa sikap yang mendukung perubahan organisasi secara langsung berdampak pada OCB dan diikuti job satisfaction. Rosenberg (1993) menjelaskan bahwa sikap karyawan pada organisasinya akan berpengaruh pada perilaku individu tersebut.

\section{Dinamika Orgaizational-Based Self Esteem, Efikasi diri, dan Organizational Citizenship Behavior}

Didasari oleh teori tahapan kognitif yang terdiri dari nilai, orientasi nilai sebagai dasar keyakinan, sikap dari norma, niat perilaku, dan perilaku (Rokeach, 1980, Vaske \& Donnelly, 1999). Persepsi efikasi pada level tugas yang lebih spesifik berkontribusi pada harga diri, karena seluruh jenis persepsi efikasi pada tugas organisasi berkontribusi terhadap harga diri dalam organisasi dan merupakan akumulasi seluruh jenis tugas dan kontribusi peraturan untuk membentuk formasi harga diri secara umum 
(Pierce \& Gardner, 1998). OBSE berbeda dengan persepsi efikasi diri karena OBSE merefleksikan kemampuan rasa diri individu dengan organisasi, sedangkan efikasi diri merefleksikan keyakinan yang mampu dirasakan dapat diterjemahkan dalam aksi yang menjadi hasil dari keberhasilan kinerja (Pierce \& Gardner, 1998). OCB pada hakikatnya merupakan perilaku individu (Pasmore \& Fagen, 1992) yang mencerminkan partisipasi aktifnya dalam mentransfer sistem di tempat individu tersebut bekerja ataupun beraktifitas.

Conley (2006) serta Cotrill (2011) memaparkan bahwa OBSE memberikan kontribusi yang positif terhadap pembentukan efikasi diri dan perilaku ideal dalam skala individu ataupun secara kolektif pada level organisasi. Hal itu didasarkan pada penelitian-penelitian mereka yang menjelaskan teori yang terkait dengan sikap, persepsi, dan perilaku anggota organisasi/karyawan. Pierce, Gardner, Dunham, \& Cummings (1993) berargumen bahwa anggota organisasi yang memiliki OBSE rendah akan menjadi lebih reaktif dibanding yang memiliki OBSE tinggi. Hal itu rentan terjadi ketika ada konflik, ketidakpastian, overload, dan lingkungan kerja yang kurang baik, serta kurangnya dukungan dari pemimpinnya. Mansor, Darus, dan Dali (2013) menjelaskan bahwa efikasi diri positif berhubungan dengan pembentukan OCB sehingga dapat meningkatkan prestasi siswa secara kelompok ataupun indivdu. Didukung oleh Copper (2010) bahwa efikasi diri pada guru secara kolektif akan meningkatkan dan membangun perilaku ideal baik secara individu ataupun kelompok para siswa sehingga kinerja sekolah lebih efekktif.

Dinamika hubungan dari peran OBSE adalah berkontribusi terhadap pembentukan persepsi dan sikap efikasi diri pada anggota organiasi serta perilaku OCB baik pada individu ataupun organisasi, sebagai proses sosialisasi organisasi yang akan saling mempengaruhi. Berdasarkan definisi konseptual dari skema hubungnan ketiga variable tersebut, maka dapat digambarkan kerangka hubungan ketiganya dalam gambar 1. sebagai berikut:

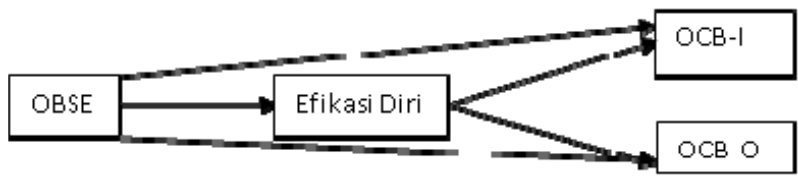

Gambar 1

Kerangka Konseptual Hubungan OBSE, Efikasi Diri, dan OCB

Dari dinamika kerangka konseptual hubungan variabel OBSE, efikasi diri dan OCB, maka dapat dihipotesiskan sebagai berikut:

\section{OBSE dan Efikasi diri}

Conley (2006) menjelaskan bahwa anggota organisasi yang memiliki harga diri yang tinggi akan menjadi lebih percaya diri dengan kemampuannya dan mempengaruhi kelompoknya (Gardner \& Pierce,1998; Hui \& Lam, 2000), Peran OBSE sebagai pengarah dan pendukung efikasi karyawan (Conley, 2006). Efikasi menggambarkan mengenai kualitas persepsi individu dalam menghadapi suatu kondisi dan menunjukkan suatu perilaku yang berulang serta berdampak positif terhadap pencapaian tujuan organsiasi (Conley, 2006; Gundlach, Martinko,\& Douglas, 2003). Karyawan yang memiiliki OBSE tinggi akan secara ikhlas memperlihatkan kinerja terbaiknya untuk bekerja karena mereka percaya diri dengan kadar kemapuannya (Conley, 2006; Mosholder, dkk, 1982). Berdasarkan uraian di atas maka mengantarkan hiposesis pada penelitian ini bahwa: H1: OBSE berpengaruh signifikan terhadap Efikasi Diri karyawan.

\section{Efikasi Diri dan OCB}

Peran efikasi diri meningkatkan perilaku yang ideal (Frayne \& Latham, 1987), meningkatkan kinerja (Mathieu, dkk, 1993). Copper (2013) juga menegaskan bahwa efikasi 
dan OCB akan memberikan kontribusi bagi keberhasilan dan efektitivitas organisasi. Hal yang melandasi bahwa keyakinan efikasi baik secara individu atau kolektif dapat memperilaku terbentuknya perilaku ideal/OCB adalah efikasi terdiri dari tiga domain yang saling berhubungan, yaitu: pertama, efikasi individu mengenai kemampuan mereka dalam menyelesaikan tugas akan berdampak pada orang lain/ rekan kerja/ bawahannya untuk dapat juga menyelesaikan tugas tersebut. Kedua, keyakinan efikasi menjelaskan kemampuan penyelesaian tugas baik secara individu ataupun kelompok berdasarkan fungsi atau peran pemimpin yang memiliki efikasi yang tinggi. Ketiga, keyakinan efikasi merupakan gambaran mengenai bagaimana individu/anggota organisasi/pemimpin/kelompok kerja melakukan penanganan terhadap stres yang dihadapi dalam mengimplementasikan suatu keinovatifan. Merujuk pada argumen terbut maka hipotesisi penelitian ini yang terkait dengan hubungan efikasi terhadap OCB, dirumuskan sebagai berikut: H2: Efikasi Diri berpengaruh signifikan terhadap OCB-I; dan H3: Efikasi Diri berpengaruh signifikan terhadap OCB-O

\section{OBSE dan OCB}

Adapun peran OBSE dalam membentuk OCB pada individu adalah sebagaimana yang jelaskan oleh Chein (2004) yang menjelaskan bahwa:

Individuals with high collectivism and propensity to trust are more likely to believe they can be a valued part of the organization, to value this role, and because of this belief, engage in behaviors to make a difference in the organization. (Chein, 2004)

Cotrill (2011) menjelaskan karyawan yang memiliki OBSE yang tinggi maka akan mengarahkan pada perilaku ideal diluar harapan organisasi, karena mereka akan menjadi percaya diri dan bangga menjadi bagian dari organisasi.
Berdasarkan uraian di atas maka hipotesis penelitian ini adalah: H4: OBSE berpengaruh signifikan terhadap OCB-I; dan H5: OBSE berpengaruh signifikan terhadap OCB-O.

\section{OBSE, Efikasi diri, dan OCB}

Konstruk teori dan empirik pada penelitian sebelumnya belum membahas mengenai peran OBSE dan efikasi diri; OBSE dan OCB (Conley, 2006; Cotrill, 2011), Efikasi diri dan OCB (Copper, 2006; Mansor, Darus, \& Dali, 2013). Adapun hasil penelitian mereka secara positif hipotesisnya terpenuhi. Bahwa berdasarkan konsep mengenai keyakinan, sikap, dan perilaku mengarahkan terhadap kontruks bahwa keyakinan akan diri individu akan harga dirinya dalam konteks organisasi akan secara kolektif mempengaruhi keyakinan efikasi diri dan orang lain, sehingga secara kolektif juga akan mempengaruhi pembantukan dan aktualisasi perilaku yang positif yaitu OCB baik individu ataupun organisasi. Maka berdasarkan kerangka itu penelitian ini menghipotesiskan bahwa OBSE berdampak positif terhadap pembentukan OCB-I dan $\mathrm{O}$ yang dimediasi oleh efikasi diri secara kolektif. Adapun penjabaran hipotesisnya adalah: H6: OBSE berpengaruh signifikan terhadap OCB-I yang dimediasi efikasi Diri; dan H7:OBSE berpengaruh signifikan positif terhadap OCB-O yang dimediasi Efikasi Diri.

\section{METODE PENELITIAN}

Populasi dalam penelitian ini adalah karyawan rumah sakit baik karyawan medis dan non-medis. Sampel yang digunakan dalam penelitian ini adalah karyawan rumah sakit golongan D yang tersebar di wilayah DI Yogyakarta yang ditentukan secara random. Jumlah responden didapatkan adalah sebanyak 222 orang baik dari kalangan medis ataupun nonmedis. Adapun analisis faktor dan uji fit model menggunakan analisis StructuralEequation 
Modeling (SEM) dengan bantuan Amos versi 18, untuk menguji hipotesis dan dalam penelitian ini menggunakan dua variabel independen yang diprediksi mempengaruhi satu variabel dependen.

Harga diri dalam Organisasi/OBSE merrupakan derajat keyakinan karyawan pada suatu organisasi yang dipersepsikan secara pribadi mengenai kemauan untuk membantu dengan berpartisipasi pada organisasi, yang mengindikasikan kedekatan karyawan terhadap organisasi (Pierce, Gardner, Cummings, \& Dunham, 1989). Indikator yang digunakan adalah live conseciously, self-accepting, responsibility, self-assertive, purposefully, dan integrity. Instrumen adaptasi dari Pierce, Garnder, Cummings, \& Dunham (1989, 1993) karena koefisien reliabilitasnya tinggi yaitu $\alpha$ 0,96 dan inter korelasi item pernyataan rit $>$ 0,3 , terdiri dari 10 item dan empat skala likert (1=sangat tidak setuju, sampai $4=$ sangat setuju). Efikasi diri yang dimaksud dalam penelitian adalah efikasi secara kolektif merupakan tingkat keyakinan individu secara bersama-sama mengenai kemampuan mereka untuk berusaha menyelesaikan tugas pekerjaannya masingmasing. Instrumen diadaptasi dari Bandura (1997) dan dikembangkan oleh (Schwarzer \& Jerusalem,1995). Terdapat tiga indikator yaitu magnitude, strength, dan generality. Instrumen ini dipilih karena koefisien reliabilitasnya tinggi yaitu $\alpha 0,8$ dan inter korelasi item pernyataan rit $>0,3$, terdiri dari 6 item dan empat skala likert (1=sangat tidak sejutu, sampai 4= sangat setuju).

OCB/Perilaku Ideal adalah perilaku yang bersifat bebas, spontan, dan sukarela terlepas dari deskripsi tugas yang memberikan kontribusi berfungsinya organisasi ke arah peningkatan efisiensi dan efektifitas pencapaian tujuan organisasi. Target perilaku karyawan dibedakan menjadi dua, yaitu: OCB-individu adalah target perilaku tertuju pada personal atau pihak lain yang terkait dengan masalah pekerjaan atau tugas dan berdampak pada berfungsinya efektifitas dan efisiensi organisasi (dimensi altruisme dan courtesy). Dan OCB-Organisasi adalah target perilaku tertuju langsung bagi kepentingan efektifitas dan efisiensi kinerja organisasi, (dimensi civic virtue, conscientiousness, dan sportsmanship). Instrumen OCB (William \& Anderson, 1991) dipilih karena koefisien reliabilitasnya tinggi yaitu $\alpha>0,6$, inter korelasi item pernyataan rit $>0,5$, terdiri dari 10 item dan empat skala likert $(1=$ sangat tidak sejutu, sampai 4= sangat setuju).

\section{HASIL PENELITIAN DAN PEMBAHASAN}

\section{Penyebaran Kuesioner Dan Karakteristik Responden}

Penelitian ini dilakukan dengan metode survei melalui penyebaran kuesioner pada karyawan rumah sakit golongan D yang tersebar di wilayah DI Yogyakarta dan ditentukan secara random. Proses pengumpulan data dilakukan selama 3 bulan. Kuesioner yang disebar sebanyak 300 buah. Dari 300 buah kuesioner tersebut ada 231 kuesioner yang berhasil dikumpulkan. Dengan demikian tingkat respon dalam penelitian ini adalah 77\%. Dari 231 kuesioner yang kembali, 9 diantaranya tidak layak untuk diolah (rusak), sehingga hanya ada 222 buah kuesioner yang dapat digunakan untuk analisis selanjutnya. Karakteristik responden yang digunakan dalam penelitian ini meliputi jenis kelamin, jenis jabatan, pendidikan, masa kerja. Secara umum, mayoritas responden adalah wanita $(83,3 \%)$ dengan jenis jabatan mayoritas sebagai tenaga medis $(63,1)$ dan masa kerja terbanyak antara 1-4 tahun. Pendidikan responden mayoritas lulusan perawat, yaitu sebesar 56,3\%.

\section{Hasil Pengujian Validitas dan Reliabilitas}

Tingkat validitas diuji dengan menggunakan uji validity dengan mengajukan butirbutir pertanyaan yang mempunyai loading factor yang signifikan, yaitu harus ${ }^{3} 0,40$ dan tidak 
menjadi bagian atau anggota factor lainnya. Semua butir pertanyaan dinyatakan valid dan selanjutnya dapat digunakan dalam pengujian.

Reliabilitas dinilai dengan menggunakan nilai koefisien Cronbach's Alpha yang bertujuan untuk mengetahui kekonsistenan suatu alat ukur dalam mengukur. Nilai Cronbach's Alpha dalam penelitian ini menggunakan nilai sebesar 0,6. Menurut Hair et al. (2006), nilai koefisien ini masih dapat diterima. Namun hasil uji reliabilitas menunjukkan bahwa terdapat beberapa item to total correlation berskor dibawah 0,5 yang tetap digunakan. Hal ini tetap digunakan karena jika dieliminasi, maka akan memperkecil koefisien Cronbach's Alpha.

\section{Evaluasi Asumsi Model Struktural}

Jumlah sample yang dapat diolah dalam penelitian ini adalah 222 responden. Berdasarkan teknik Maximum Likelihood Estimation (MLE), jumlah minimum sample yang direkomendasikan adalah 200 (Hair et al.,2006;741) atau 5 kali parameter yang diestimasi (Hair et al.,2006), sehingga jumlah sampel penelitian ini diterima.

Semua butir-butir pertanyaan menunjukkan nilai critical ratio skewness value berada jauh di bawah nilai kritis 2,58. Hanya ada 3 butir pertanyaan yaitu X12,X13, dan X14 yang nilainya diatas nilai kritis. Secara multivariate, data dalam penelitian ini juga berdistribusi normal karena nilai critical ratio untuk normalitas multivariate adalah 0,530. Oleh karena itu dapat dikatakan bahwa secara umum data dalam penelitian ini berdistribusi normal.

Dalam analisis multvariat adanya outliers dapat diuji dengan menggunakan Mahalanobis $\left(\mathrm{D}^{2}\right)$ dibagi degree of freedom $\left(\mathrm{D}^{2} / \mathrm{df}\right)$. Suatu data dikatakan Outliers apabila mahalanobis distance lebih besar dari $\chi^{2}(14 ; 0.01)=34,27$. Hasil pengujian menunjukkan bahwa tidak ada data yang outliers.

\section{Pengujian Model Struktural}

Model structural yang dibangun dari model penelitian ini setelah diolah dengan menggunakan program AMOS 18.0 dapat dilihat hasilnya adalah sebagai berikut:

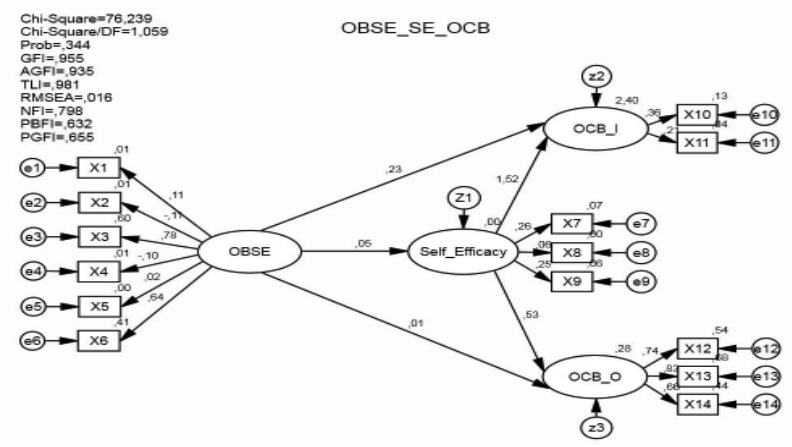

Gambar 2

\section{Model Struktural}

Hasil pengujian kesesuaian model penelitian dijelaskan dalam tabel 1 berikut:

Tabel 1

Hasil Pengujian Kesesuaian Model

\begin{tabular}{lccc}
\hline \multicolumn{1}{c}{ Indeks } & Cut of Value & Hasil & Keterangan \\
\hline$\left(\chi^{2}\right)$-Chi square & Diharapkan & 76,239 & Marginal \\
Significance & Kecil & & \\
Probability & $\geq 0,05$ & 0.344 & Baik \\
RMSEA & $\leq 0,08$ & 0.016 & Baik \\
GFI & $\geq 0,90$ & 0.955 & Baik \\
AGFI & $\geq 0,90$ & 0.935 & Baik \\
CMIN/DF & $\leq 2,00$ & 1.059 & Baik \\
TLI & $\geq 0,90$ & 0.981 & Baik \\
CFI & $\geq 0,90$ & 0.985 & Baik \\
NFI & $\geq 0,90$ & 0.798 & Marginal \\
\hline
\end{tabular}

Sumber: Hasil Pengujian Kesesuaian Model Output AMOS 18.0

Hasil pengujian kesesuaian model menunjukkan bahwa model structural yang diestimasi adalah baik. Kecuali untuk Chi square dengan besar 76,239 dan NFI yang masih di bawah 0,90 dengan posisi marginal. Nilai Chi square sangat sensitive terhadap jumlah sample. Semakin besar sample semakin signifikan. Namun demikian, model dapat diterima sebagai model penelitian, karena secara umum model ini memiliki tingkat kesesuaian yang baik. Hal ini terlihat dari nilai indeks yang memenuhi cut of value. 
Dalam AMOS 18.0, hubungan antar konstruk dalam hipotesis ditunjukkan oleh nilai standardized regression weight. Hubungan kausalitas dikatakan signifikan apabila nilai parameter estimasi memiliki nilai kritisnya $\geq$ 1,96 (tingkat signifikansi 0,05), dan pada tingkat signifikansi 0,01 nilai kritisnya adalah $\geq 2,58$ (Hair et al.,2006;82). Hasil regression weight model structural penelitian ini dijelaskan dalam tabel 2.

\section{Tabel 2}

Regression Weight Model Struktural

\begin{tabular}{|c|c|c|c|c|c|c|}
\hline & & & $\begin{array}{l}\begin{array}{l}\text { Unstan- } \\
\text { dardize }\end{array} \\
\text { Estimate }\end{array}$ & S.E. & C.R. & $\begin{array}{c}\text { Stan- } \\
\text { dardized } \\
\text { Estimate }\end{array}$ \\
\hline $\begin{array}{l}\text { Self_- } \\
\text { Efficacy }\end{array}$ & $<---$ & OBSE & 1,017 & , 482 & $2,209^{*}$ & ,448 \\
\hline OCB_I & $\begin{array}{l}<--- \\
<---\end{array}$ & $\begin{array}{l}\text { OBSE } \\
\text { OBSE }\end{array}$ & $\begin{array}{l}114 \\
, 017\end{array}$ & $\begin{array}{l}185 \\
, 161\end{array}$ & $\begin{array}{l}619 \\
, 106\end{array}$ & $\begin{array}{l}, 225 \\
, 015\end{array}$ \\
\hline OCB_I & $<---$ & Self- & 2,160 & 1,031 & $2,095^{*}$ & 1,524 \\
\hline OCB_O & $<--$ & $\begin{array}{l}\text { Self- } \\
\text { Efficacy }\end{array}$ & 1,710 & ,736 & $2,323 *$ &, 529 \\
\hline $\begin{array}{l}\text { X11 } \\
\text { X10 } \\
\text { X13 } \\
\text { X14 } \\
\text { X12 }\end{array}$ & $\begin{array}{l}<--- \\
<--- \\
<--- \\
<--- \\
<---\end{array}$ & $\begin{array}{l}\text { OCB_I } \\
\text { OCB-I } \\
\text { OCB-O } \\
\text { OCB_O } \\
\text { OCB_O }\end{array}$ & $\begin{array}{l}, 579 \\
1,000 \\
1,016 \\
, 774 \\
1,000\end{array}$ & $\begin{array}{l}, 238 \\
, 112 \\
, 090\end{array}$ & $\begin{array}{l}2,434 * \\
9,065^{* *} \\
8,563^{* *}\end{array}$ & $\begin{array}{l}, 208 \\
, 364 \\
, 827 \\
, 665 \\
, 736\end{array}$ \\
\hline $\mathrm{X} 8$ & $<---$ & $\begin{array}{l}\text { Self_- } \\
\text { Efficacy }\end{array}$ &, 253 & ,420 & ,601 &, 058 \\
\hline X9 & $<---$ & $\begin{array}{l}\text { Self- } \\
\text { Efficacy }\end{array}$ & 1,030 &, 534 & 1,929 &, 250 \\
\hline $\mathrm{X} 7$ & $<--$ & $\begin{array}{l}\text { Self- } \\
\text { Efficacy }\end{array}$ & 1,000 & & & ,261 \\
\hline $\begin{array}{l}\text { X6 } \\
X 5 \\
X 4 \\
X 1 \\
X 2 \\
X 3 \\
\end{array}$ & $\begin{array}{l}<--- \\
<--- \\
<--- \\
<--- \\
<--- \\
<--- \\
\end{array}$ & $\begin{array}{l}\text { OBSE } \\
\text { OBSE } \\
\text { OBSE } \\
\text { OBSE } \\
\text { OBSE } \\
\text { OBSE }\end{array}$ & $\begin{array}{c}1,000 \\
, 023 \\
-, 153 \\
, 157 \\
-, 253 \\
1,064 \\
\end{array}$ & $\begin{array}{l}, 119 \\
, 123 \\
, 121 \\
, 187 \\
.471 \\
\end{array}$ & $\begin{array}{c}195 \\
-1,249 \\
1,295 \\
-1,359 \\
2,258^{*} \\
\end{array}$ & $\begin{array}{c}, 642 \\
, 016 \\
-, 103 \\
, 107 \\
-, 112 \\
, 777 \\
\end{array}$ \\
\hline
\end{tabular}

level 0,05

Sumber: Hasil Pengujian Regression Weight Model Struktural Output AMOS 18.0

Pengujian hipotesis 1 dilakukan untuk mengetahui pengaruh signifikan OBSE pada efikasi diri (Self-efficacy) karyawan. Signifikansi diperoleh apabila nilai critical ratio $\geq 1,96$ pada tingkat signifikansi 0,05. Berdasarkan hasil output AMOS 18.0 (table 7), nilai C.R pada hubungan antara OBSE dengan Self-efficacy adalah 2,209. Hasil tersebut menunjukkan bahwa hipotesis satu didukung (pada tingkat signifikansi 0,05), yaitu OBSE berpengaruh signifikan terhadap Selfefficacy. Pengujian hipotesis 2 dilakukan untuk mengetahui pengaruh signifikan antara Self- efficacy pada OCB-I. Hasil menunjukkan bahwa hubungan antara Self-efficacy dengan OCB-I memiliki nilai C.R sebesar 2.095. Berdasar criteria yang ditetapkan yaitu C.R $\geq 1,96$ (pada tingkat signifikansi 0,05), maka hipotesis 2 ini diterima. Hasil ini mengindikasikan bahwa Selfefficacy berpengaruh signifikan terhadap OCB-I.

Pengujian hipotesis 3 dilakukan untuk mengetahui pengaruh signifikan antara Selfefficacy pada OCB-O. Hasil menunjukkan bahwa hubungan antara Self-efficacy dengan OCB-O memiliki nilai C.R sebesar 2.095. Berdasar criteria yang ditetapkan yaitu C.R $\geq 1,96$ (pada tingkat signifikansi 0,05), maka hipotesis 3 ini diterima. Hasil ini mengindikasikan bahwa Self-efficacy berpengaruh signifikan terhadap OCB-O. Pengujian hipotesis 4 dilakukan untuk mengetahui pengaruh signifikan OBSE pada OCB-I. Signifikansi diperoleh apabila nilai critical ratio $\geq 1,96$ pada tingkat signifikansi 0,05. Berdasarkan hasil output AMOS 18.0 (table 7), nilai C.R pada hubungan antara OBSE dengan OCB-I adalah 0,619. Hasil tersebut menunjukkan bahwa hipotesis 4 tidak didukung (pada tingkat signifikansi 0,05), yaitu OBSE tidak berpengaruh signifikan terhadap OCB-I.

Pengujian hipotesis 5 dilakukan untuk mengetahui pengaruh signifikan OBSE pada OCB-O. Signifikansi diperoleh apabila nilai critical ratio $\geq 1,96$ pada tingkat signifikansi 0,05. Berdasarkan hasil output AMOS 18.0 (table 7), nilai C.R pada hubungan antara OBSE dengan OCB-I adalah 0,106. Hasil tersebut menunjukkan bahwa hipotesis 5 tidak didukung (pada tingkat signifikansi 0,05), yaitu OBSE tidak berpengaruh signifikan terhadap OCB-O. Hipotesis keenam bertujuan untuk menguji peran mediasi self efficacy pada hubungan antara OBSE dengan OCB-I. Tabel 7. menunjukkan bahwa nilai critical ratio pada hubungan OBSE dengan self efficacy adalah 2,209 dan critical ratio untuk hubungan self efficacy dan OCB-I sebesar 2,095, hal ini berarti signifikan pada level 
0,05. Nilai ini mengindikasikan bahwa hipotesis keenam didukung, artinya self efficacy memediasi hubungan antara OBSE dengan OCB-I. Hipotesis ketujuh bertujuan untuk menguji peran mediasi self efficacy pada hubungan OBSE dengan OCB-O. Tabel 7. menunjukkan bahwa nilai critical ratio pada hubungan OBSE dengan self efficacy adalah 2,209 dan critical ratio untuk hubungan self efficacy dan OCB-O sebesar 2,323 (signifikan pada level 0,05). Nilai ini mengindikasikan bahwa hipotesis ketujuh didukung, artinya self efficacy memediasi hubungan antara OBSE dengan OCB-O.

\section{Pembahasan}

Penelitian ini bertujuan untuk menguji pengaruh OBSE pada self-efficacy, OCB-I dan OCB-O. Penelitian ini dilakukan terhadap 222 orang tenaga medis dan nonmedis rumah sakit kategori D di wilayah DI. Yogyakarta. Hipotesis 1: OBSE terbukti secara signifikan berhubungan dengan self-efficacy dan mengindikasikan bahwa karyawan rumah sakit yang mempunyai harga diri tinggi dalam konteks organisasi, akan meningkatkan keyakinan individu secara bersama-sama mengenai kemampuan mereka untuk berusaha menyelesaikan tugas pekerjaannya masing-masing. Hasil ini mendukung penelitian yang dilakukan oleh Conley (2006) dan Cotrill (2011) bahwa OBSE berhubungan siginifikan terhadap pembentukan efikasi diri. Hipotesis 2 dan 3 menguji pengaruh signifikan antara Selfefficacy pada OCB-I dan OCB-O. Karyawan yang berkemampuan tinggi cenderung akan berbuat hal yang terbaik bagi organisasinya, sehingga akan memunculkan perilaku positif yang mempengaruhi efektifitas dan efisiensi organisasi. Jika banyak individu yang melakukan perilaku ideal, maka tujuan organisasi akan cepat tercapai. Hasil ini mendukung penelitian yang telah dilakukan oleh Mansor, Darus, dan
Dali (2013) yang menemukan bahwa efikasi diri positif berhubungan dengan pembentukan OCB, sehingga dapat meningkatkan prestasi siswa secara kelompok ataupun indivdu.

Hasil hipotesis keempat dan kelima (H4 \& H5) menunjukkan bahwa OBSE tidak berpengaruh secara signifikan terhadap perilaku ideal karyawan rumah sakit baik dalam level individu maupun organisasi. Karyawan rumah sakit yang memiliki harga diri yang tinggi tidak selalu menunjukkan perilaku idealnya baik dalam level individu maupun dalam level organisasi. Hasil penelitian ini tidak mendukung penelitian yang telah dilakukan oleh Conley (2006) serta Cotrill (2011) yang memaparkan bahwa OBSE memberikan kontribusi yang positif terhadap pembentukan efikasi diri dan perilaku ideal dalam skala individu ataupun secara kolektif pada level organisasi. Pengujian hipotesis keenam (H6) dan ketujuh (H7) dilakukan untuk mengetahui peran mediasi self efficacy pada hubungan OBSE dengan OCB-I dan OCB-O. Karyawan tenaga medis dan non medis pada rumah sakit yang memiliki harga diri yang tinggi ternyata tidak langsung memberikan kontribusi positif dalam pembentukan perilaku ideal baik dalam skala individu maupun organisasi. Munculnya perilaku ideal ternyata dipengaruhi oleh tingkat kemampuan karyawan untuk menyelesaikan pekerjaannya. Individu yang mempunyai harga diri yang tinggi tersebut akan menunjukkan perilaku idealnya jika dia merasa mampu untuk melakukan pekerjaan tersebut. Hal ini sangat dimengerti mengingat pekerjaan di Rumah Sakit memiliki tingkat resiko yang tinggi, artinya jika sesorang tidak punya kemampuan menyelesaikan pekerjaan, maka lebih baik tidak melakukan pekerjaan tersebut. Hal ini berarti bahwa self efficacy memiliki peran mediasi bagi hubungan antara OBSE dan OCB baik pada level individu maupun pada level organisasi. 


\section{KESIMPULAN DAN SARAN}

\section{Kesimpulan}

Dari hasil penelitian dapat disimpulkan bahwa: pertama, OBSE secara parsial berpengaruh signifikan pada self efficacy, tetapi tidak berpengaruh signifikan terhadap OCB baik dalam level individu maupun level organisasi. Sedangkan self efficacy berpengaruh signifikan terhadap OCB level individu dan level organisasi. Kedua, Self efficacy secara signifikan memediasi hubungan OBSE dan OCB level individu dan level organisasi. Peran self efficacy dalam memediasi hubungan OBSE dengan OCB level individu dan OCB level organisasi bersifat parsial. Dengan demikian karyawan rumah sakit akan lebih menunjukkan perilaku idealnya jika memiliki kemampuan untuk menyelesaikan pekerjaan tersebut. Dan ketiga, Model struktural yang diestimasi memiliki tingkat kesesuaian yang cukup baik. Hal ini terlihat dari berbagai kriteria goodness of fitnya, yaitu: Chi-Square: 76,239 (marginal), Significance Probability: 0,344 (baik), RMSEA: 0,016 (baik), GFI: 0,955 (baik), AGFI: 0,935 (baik), CMIN/DF: 1,059 (baik), TLI: 0,981 (baik), CFI: 0,985 (baik), NFI: 0,798 (marginal).

\section{Saran}

Untuk penelitian selanjutnya, peneliti menyarankan beberapa hal. Pertama, penelitian selanjutnya sebaiknya menggunakan sampel untuk golongan rumah sakit yang berbeda. Dengan menggunakan responden dari beberapagolongan rumah sakit yang berbeda diharapkan mampu meningkatkan validitas ekternal dari model yang diusulkan. Kedua, penelitian selanjutnya diharapkan memperhatikan data demografi responden, agar jawabannya lebih akurat dan terlihat jelas perbedaannya. Ketiga, peneliti selanjutnya diharapkan dapat menggunakan metode pende- katan kuantitatif dan kualitatif untuk dapat menggali dinamika perilaku ketiga variabel lebih mendalam sehingga akan memperkuat fundamental teori penelitian ini.

\section{DAFTAR PUSTAKA}

Bandura, (1997). Self Efficacy The Exercise of Control. New York: W.H. freean and Compeny.

Chien, M. (2004). An investigation of the relationship of organizational structure, employee's personality and organizational citizenship behaviors. Journal of American Academy of Business, 5 (1/2), 428(4). Retrieved May 31, 2005, from ProQuest database.

Chih, W-H. W., Yang, F-H. \& Chang, C-K. (2012). The study of the antecedents and outcomes of attitude toward organizational change. Public Personnel Management, 41(4). 597-617.

Choi, J. N., Price, R. H., \& Vinokur, A. D.(2003). Self-efficacy changes in groups: effectsof diversity,leadership, and group climate. Journal of Organizational Behavior, 24. 357-372.

Conley, V. P. (2006). An investigation of organization-based self-esteem in an automotive manufacturing company. Dissertation unpublication University of Pheonix: USA.

Copper, J.D. (2010). Collective efficacy, organizational citizenship behavior, and school effectivenes in Alabama public high school. Disertasi untuk Program Doktor Pendidikan, Departemen Pendidikan Kepemimpinan, Penelitian Peraturan dan Teknologi, Universitas Alabama: USA.

Cottrill, K. R. (2011). Antecedents and outcome of inclusion: Exploring authentic leadership, organizational climate 
for ethics, organization-based selfesteem, and organizational citizenship behaviors. Dissertation publication UMI, Alliant International University: Los Angeles.Cremer, D. D., van Knippenberg, D., M., van Knippenberg, B., Mullenders, D., \& Stinglhamber, F. (2005). Rewarding leadership and fair procedures as determinants of selfesteem. Journal of Appllied Psychology, 90(1). 3-12.

Frayne, C.A. \& Latham, G.P. (1987). Application od social learning theory to employee self-management of attendace. Journal of applied psychology, 72(3). 387-392.

Garnder, D. G., \& Pierce, J. L.(1998). Selfesteem and self -efficacy within theorganizasional context: An empirical examination. Group and Organization Management, 23 (1). 48-70.

Gundlach, M., Martinko, M., \& Douglas, S. (2003). Emotional intelligence, causal reasoning and the self-efficacy development process. International Journal of Organizational Analysis, 11(3), 229.

Hui, C., Law, K.K.S., \& Lam, S. S. K. (2000). Research report:Instrumental value of organizational citizenship behavior for promotion: A field quasi-experiment. Journal of applied psychology, 85 (5). 822-828.

Kreitner, R. \& Kinicki, A. (2004). Organizational Behavior, Sixth Edition. USA: McGrawHill.

Kumar, R., \& Uzkurt, C. (2013). Investigating the effects of self efficacy on innovativeness and the moderating impact of culture dimensions. Journal of International Business and Culture Studies. 1-15.

Korman, A. K. (1976). Hypothesis of work behavior revisited and an extension. Academy of Management Review, 1. 5063.
Mansor, A., Darus, A., \& Dali, M.H. (2013). Mediatong effest of self-efficacy on selfleadership and teachers' organizational citizenship behavior: A conceptual framework. International Journal of Economics Business and Management Studies. 2(1). 01-11.

Mossholder, K. W., Bedeian, A. G., \& Armenakis, A. A. (1982). Group process-work outcome relationship: A note on the moderating impact of self-esteem. Academy of Management Journal, 25. 575-585.

Organ, D. W. (1988). Organizational Citizenship Behavior. Lexington, MA: Lexington.

Pasmore, W.A., \& Fagans, M. R. (1992). Participation, individual development, and organization change: A review and synthesis. Journal of Management, 18(2). 375-397.

Pierce, J.L.,\& Gardner, D. G. (1989). Self-esteem within the work and organizational context: A review of the organizationbases self-esteem literaure. Journal of Management. 30(5).591-622.

Pierce, J.L.,Gardner, D. G., Cummings, L. L., \& Dunham, R. B. (1989). Organizationbased self-esteem construct definition, measurenment, and validation. Academy of Management Journal, 32(3). 622-648.

Pierce, J. L., Gardner, D. G., Cummings, L. L., \& Dunham, R.B. (1993). Moderation by organization-based self-esteem of role condition-employee response relationships. Academy of Management, 36(2). 271-288.

Robins, S. P., \& Judge, T. A. (2009). Perilaku Organisasi, Edisi2. Salemba Empat: Jakarta.

Rokeach, M. (1980). Beliefs, Attitudes, and Values: A Theory of Organization and Change. USA: Jossey-Bass Publishers. 
Rosenberg, M. (1993). Society and The Adolescent self-image. Pricenton, N: Pricenton University Press.

Schepman, S., \& Richmond, L. (2003). Employee expectations and motivation: An application from the "learned helplessness" paradigm. Journal of American Academy of Business, 3(1/2), 405. Retrieved May 1, 2005, from ProQuest database.

Schwarzer, R., \& Jerusalem, M. (1995) Generalized Self-Efficacy Scale. In Weinman, J, S. Wright, and M. Johnson (Eds.) Measures in health psychology: A User's Portfolio, Causal and Control Beliefs (pp. 35-37). Windsor, England: NFER-NELSON.

Strauser, Ketz, \& Keim (2002). The relationship between self-efficacy, locus of control and work personality. (Self-Efficacy and Locus of Control). The Journal of Rehabilitation, 68(1), 20(7). Retrieved April 25, 2005, from ProQuest database.
Suresh, S., \& Venkatammal,P.(2010). Antecedents of organizational citizenship behavior. Journal the Indian Academy of Applied Psychology, 36 (2). 276-286.

Tschannen-Moran, M. Gareis, C. (2004). Principals' sense of efficacy: Assessing a promising construct. Journal of Educational Administration, 42(4/5), 573. Retrieved May 31, 2005, from ProQuest database.

Van Dyne, L., \& Pierce, J. L.(2004). Psychological ownership and feelings of possession: Three field studies predicting employee attitudes and organizational citizenship behavior. Journal of Organizational Behavior, 25. 439-459.

Vaske, J. J., \& Donnelly, M. P. (1999). A valueattitude-behavior model predicting wildland preservation voting intentions. Society \& Natural Resources, 12. 523537.

William, L.J.,\& Anderson, S. E. (1991). Job satisfation and organizational commitment as predistore of OCB and in-role behaviors. Journal of Management, 17. 601-617. 